\title{
New Terpenoid From The Rhizomes Of Cyperus Scariosus
}

\author{
Shachi Sahu, Member IACSIT, Jagdamba Singh, Shiv Kumar, Member IAENG \& IACSIT
}

\begin{abstract}
These Phytochemical invetigation of Cyperus scariosus leads to the isolation and identification of a compound2,3-diacetoxy-19-hydroxy-urs-12-ene-24-O- $\beta$-D-xylo pyranoside 1 based on chemical and spectroscopic studies. Cyperus scariosus syn (Cyperacae) commonly known as Nagarmotha. The plant is generally distributed in damp places in Bengal, Sundarbans, Utter Pradesh and eastern and southern parts of India. It is also grown in Australia. This plant has been reported to have many medicinal properties.

In continuation of our research for medicinal plants, we report, herein, isolation and structure elucidation of new compounds from Cyperus scariosus.
\end{abstract}

Index Terms-Phytochemical investigation, Cyperus scariosus, Cyperacae Nagarmotha

\section{INTRODUCTION}

The history of medicine and surgery dates back perhaps to the origin of the human race. But, as no mode of recording events existed in prehistoric times, there are no data on the methods of treatment practiced in that period. In those days, the subject of human suffering and its alleviation was intimately associated with religion, myth and magic. In addition, there must have been certain rational prescriptions. Whenever the curiosity of the present day man probes into the past and brings to light even fragmentary information on the ingenious methods of our ancestors, it makes a fascinating study.

In India, the references to the curative properties of some herbs in the Rigveda seem to be the earliest records of use of plants in medicine. The identity of several plants referred to in the Suktas of the Rigveda can be fixed with reasonable certainty, e.g. of Semal, Pithvan, Palash and Pipal. But references to plants in the Rigveda are very brief. A more detailed account is available in the Atharva-Veda.

Then appeared the two most important works on Indian system of medicine. The works of Charak and Susruta, namely, the Charak- Samhita, Susruta-Samhita. Susruta-Samhita deals with about 700 drugs, some of these

Manuscript received March 31, 2010

Dr. Shachi Sahu is with Department of Engg. Chemistry, Technocrat Institute of Technology \& Excellence-Bhopal (M.P.)-India (Mobile No.: +91-9977830424, e-mail: shachisahu@yahoo.com).

Dr. (Prof.) Jagdamba Singh is professor in the Department of Chemistry, University of Allahabad, Allahabad (U.P.)-India (Mobile No.: +91-9415218507, e-mail: dr.jdsau@gmail.com).

Shiv Kumar is with Department of Information Technology, Technocrat Institute of Technology-Bhopal (M.P.)-India (Mobile No.: +91-9827318266, e-mail: shivksahu@rediffmail.com). were not indigenous to India. With the passing of time, more and more plants found entry into native medicine, taking the number of Indian medicinal herbs to about 1.500 .

The medicinal value of drug plants is due to presence of some chemical substances in the plant tissue which produce a definite physiological action on the human body. The most important chemical substances are alkaloids, terpenes, sterols, glycosides, saponins, gums, fatty acids, lactones, coumarins, carbohydrates, essential oils, waxes, amino acids, proteins, tanins, enzymes, resins, hydrocarbons, colouring matters, aliphatic ketones, esters and alcohols etc.

The chemical composition of a drug is the key to its pharmacological action. The potentialities of some of these drugs have long been established but a great majority of the plants remain still untouched. One of the main problems encountered with chemists, pharmacologists and medicinal practitioners in ayurvedic and other systems of medicines, is the collection and determination of the plant materials. In fact, anything that leads to the greater utilization of our natural products deserves encouragement. With the development of new chromatography,HPLC,UV,IR, ${ }^{1} \mathrm{HNMR},{ }^{13} \mathrm{C}$ NMR and mass spectroscopy and their application in structural elucidation of organic compounds together with the spectacular advancement of knowledge on biogenesis of natural products, the chemistry of natural product is making rapid and tremendous progress. With the advent of such modern techniques, it has become easier to elucidate the nature and the structures of chemical compounds of natural products in a relatively short time, even from a few milligrams of substance, responsible for their medicinal properties.

The work embodied in this paper involves the detailed chemical investigation of compound-1 of Cyperus scariosus. The plant is well known for their medicinal importance. The main objective of this investigation is to study the chemical constituents of this plant responsible for their astringency and medicinal value. The chemical investigation of the plant includes isolation and structural elucidation of different chemical constituent with help of chemical reactions and spectral studies viz. UV, IR, ${ }^{1} \mathrm{H}$ NMR, ${ }^{13} \mathrm{C}$ NMR and Mass.

Cyperus scariosus (Syn. Cyperus pertenuis Roxb.) belongs to family Cyperacae commonly known as "Nagarmotha" in Hindi ${ }^{1}$ and "Nut grass" in English ${ }^{2}$. It is generally distributed in damp places in Bengal, Sundarbans, Uttar Pradesh and Eastern and Southern parts 
of India. It is also grown in Australia ${ }^{3}$.

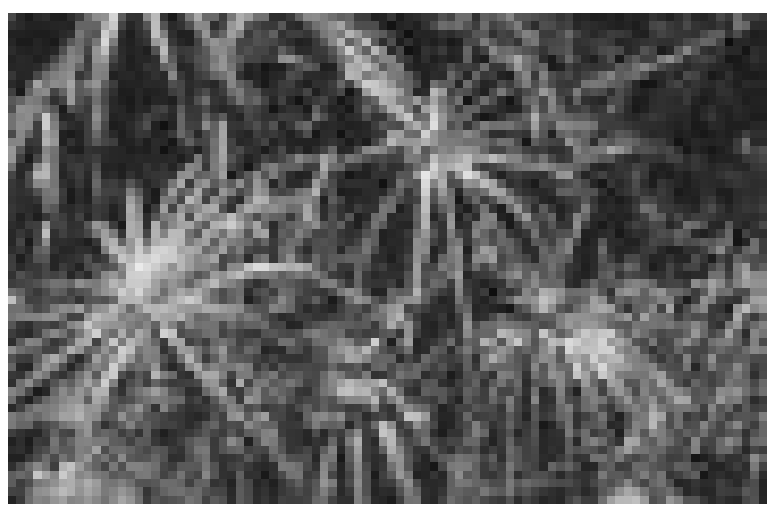

[Fig-1: Cyperus Plant]

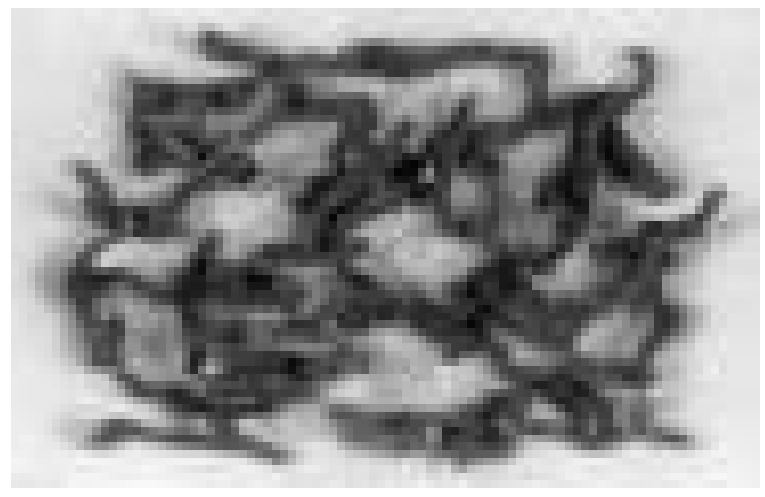

[Fig-2: Cyperus Rhiomes]

The plant is a glabrous herb. Stolons are slender, 0.8-5.0 $\mathrm{cm}$ by $0.25 \mathrm{~cm}$, clothed by elliptic, acute, lax striate concolorous scales $1 / 8$ inch long, stem $40-90 \mathrm{~cm}$ long, slender, triquetrous at top $\frac{1}{24}-\frac{1}{16}$ inch in diametre, leaves are variable, usually short (less than $1 / 3$ stem), narrow, weak, and umbels are slender, contracted, rays slender sometimes upto 3 inch long, and bracts are nearly always as the leaves i.e. hardly any when leaves short, exceeding inflorescence when leaves longish, and spikelets are linear pale straw-colour and rhizome are very short, woody, stolons, lateral shoots from base of stem immediately ascending, glumes scarcely imbricate in fruit. The plant is well known for its medicinal properties. This plants are widely used for diuratic, astringent, anti-inflammatory, antimicrobial, hypotensive, stimulant of central nervous system, useful in diarrhoea in form of a decoct and are also used in gonor and in syphilitic affections. Rhizomes are used for washing hair and as antidote to snake bite. Oil obtained from tubers (rhizomes) is used by perfumers as fixative. It forms good substitute for patchouli oil in soap and other perfumes. Oil is also used as hair tonic.

\section{Previous WORK}

On reviewing the literature it was found that from this plant following compounds were reported. Stigmasta-5,24(28)-diene-3- $\beta$ - $O$ - $\alpha$-L-rhamnopyranosyl- $O$ - $\beta$ -D-arabino-pyranoside(III) ${ }^{4}$ and a new glycoside leptosidin 6-O- $\beta$-D-glucopyranosyl- $O-\alpha$-2-rhamnopyranoside ${ }^{5}$ was isolated from the leaves and $(-)-\beta$-selinene and a new tricyclic hydrocarbon, isopatchoula-3,5-diene(IV $)^{6,7}$ isolated from Cyperus scariosus oil. Essential oil, sesquiterpene, cyperenone, cyperenol, patchoulenol, isopatchoulenone,

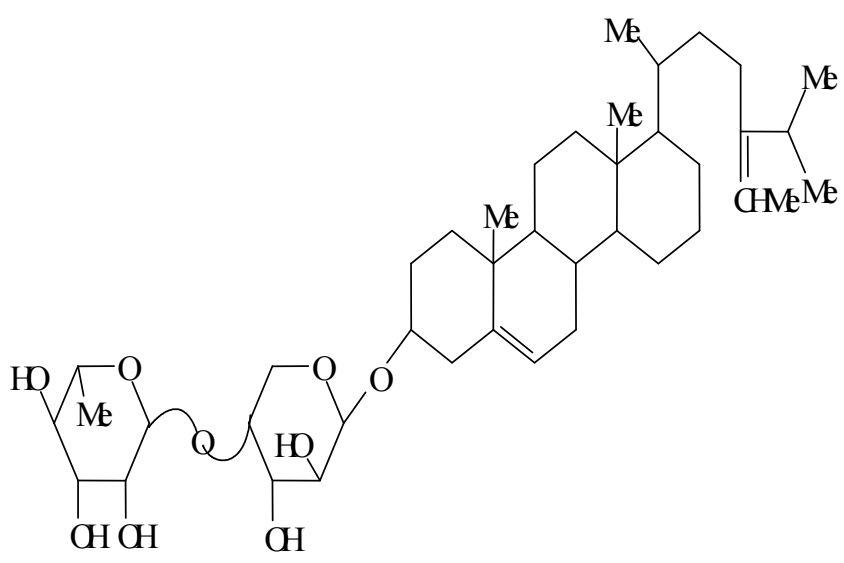

Fig.-III

retundene, rotundenol ${ }^{7}$ isolated from tuber of this plant

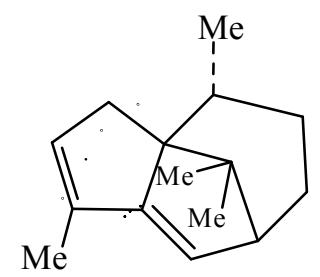

Fig.-IV

\section{DisCUSSION DETAILS}

Compound 1 , was obtained as a yellow crystal, m.p. $70^{\circ} \mathrm{C}$ was a triterpenoid glycoside; It gave positive coloration in the Salkowski ${ }^{3}$, Liebermann-Burchard ${ }^{8}$, Tschugajew ${ }^{9}$, Noller's ${ }^{10}$, Rosenheim $^{11}$, Kohlenberg's ${ }^{12}$, and Brieskorne ${ }^{13}$ test for triterpenoid. It gave yellow colour with tetranitromethane (Ruzicka reaction) ${ }^{14}$ confirming double bond at position C-12: C-13.The IR spectrum showed the absorption for hydroxyl group $\left(3300 \mathrm{~cm}^{-1}\right)$, tertiary hydroxy group 3500 $\mathrm{cm}^{-1}$, acetoxyl group $1690 \mathrm{~cm}^{-1}$ and $1100 \mathrm{~cm}^{-1}$ and C-methyl $2928 \mathrm{~cm}^{-1}$. Acid hydrolysis of 1 afforded D-xylose. The mass spectrum gave a peak at $\mathrm{m} / \mathrm{z}$ at 689 , corresponding to the molecular formula $\mathrm{C}_{39} \mathrm{H}_{61} \mathrm{O}_{10}$. ${ }^{13} \mathrm{C}$ NMR spectral data indicates that compound 1 possesses 7 methyl, 8 methylene, 6 methine and 5 quaternary carbons. The position of acetoxyl groups at $\mathrm{C}-2$ and $\mathrm{C}-3$ were confirmed by the ${ }^{1} \mathrm{H}$ NMR and ${ }^{13} \mathrm{C}$ NMR spectram ${ }^{15}$. The ${ }^{13} \mathrm{C}$ NMR spectrum of downfield shift of 24 (73.9) compound with aglycone (63.9) (Table-I). This shift can be interpreted as due to the linkage of a xylose moiety at C-24. The ${ }^{1} \mathrm{H}$ NMR spectrum showed an anomeric proton of xylose at $4.98(\mathrm{~d}, J 7 \mathrm{~Hz}, 1 \mathrm{H})$ indicative of the linkage of xylose moiety with the aglycone in the $\beta$ configuration (the larger $J$ value of xylose indicated that the anomeric center had $\beta$ configuration). Thus compound 1 was 
2,3, diacetoxy-19-hydroxy-urs-12-ene-24-O- $\beta$-D-xylopyrano side.

The air-dried and finely crushed rhizome of Cyperus scariosus was extracted with boiling ethanol. The ethanolic extract was concentrated under reduced pressure and then poured into benzene with constant stirring, a dark brown benzene soluble solution (fraction-I) and a light brown benzene insoluble residue (fraction-II) were obtained.

Practically nothing could obtain in sufficient amount from fraction-I. The benzene insoluble residue (fraction-II) was chromatographed over a sintered column, using different solvents of increasing polarity viz. hexane, benzene, chloroform, ethyl acetate and methanol. Individual fraction were also worked out separately.

Hexane: Benzene $(4: 6, \mathrm{v} / \mathrm{v})$ fraction was found to contain single compound named as Compound- 1 .

\section{SCHEME OF ISOLATION AND PURIFICATION OF COMPOUNDS FROM THE RHIZOME OF CYPERUS SCARIOSUS}

The overall Scheme of Isolation and Purification of Compounds from the Rhizome of Cypetus Scarious are given in figure-5. The basic details of Isolation and Purification of Compounds are defined by following points:

\section{A. Experimental}

The rhizome of Cyperus scariosus was purchased from Varanasi (Gola Deena Nath Mandi), U.P., India. All the spectral studies throughout the work have been done using following instruments. UV spectra were recorded on a Beckmans-DK2 spectrophotometer. IR spectra were recorded in $\mathrm{KBr}$ on a Perkin Elmer spectrometer. ${ }^{1} \mathrm{H}$ NMR and ${ }^{13} \mathrm{C}$ NMR spectra of compounds CS-1, CS-2, CS-4 and CS-6 were recorded in $\mathrm{CDCl}_{3}$ and compound CS-3 was recorded in $\mathrm{C}_{6} \mathrm{D}_{6}$ and compound $\mathrm{CS}-5$ was recorded in $\mathrm{CD}_{3} \mathrm{OD}$ using TMS as an internal standard at $300 \mathrm{MHz}$ and $75 \mathrm{MHz}$, respectively on a DRX 300 spectrometer. Mass spectra were recorded on a JEOL SX 102/DA-6000 mass spectrometer.

\section{B. Extraction with Ethanol}

The air-dried and finely crushed rhizomes $(5 \mathrm{~kg})$ of Cyperus scariosus was exhaustively extracted with ethanol $(4 \times 10$ litres) under reflux in a round bottom flask. The ethanolic extract was concentrated $(700 \mathrm{ml})$ under reduced pressure in rotatory evaporator and poured into a benzene with constant stirring, a dark brown benzene soluble solution (fraction-I) and a light brown residue (fraction-II) were obtained which were separated by filtration. Each fraction was worked out separately.

\section{Fraction-II}

The light brown residue (fraction-II) was chromatographed over a sintered column using different solvents of increasing polarity viz. Hexane, benzene, ethyl acetate and methanol respectively. Individual fractions were worked out separately.

From hexane, benzene, ethyl acetate and methanol fractions nothing could obtain in sufficient amount. From hexane: benzene $(4: 6, \mathrm{v} / \mathrm{v})$ fraction single compound CS-1, m.p. $70^{\circ} \mathrm{C}$ (400 mg) was isolated.

\section{Result ANALYSIS}

Melting points are uncorrected. Column and thin layer paper chromatographic analyses were performed at room temperature. Sugar was characterized by descending paper chromatography on whatmann no. 1 paper using n-butanol-acetic acid-water (4: 1: 5, v/v) as a developing solvent. The plant material was collected from Varanasi and identified by the Botany Department, Allahabad.

The air-dried rhizomes and powdered plant of Cyperus scariosus was extracted with $\mathrm{EtOH}$ under reflux for 15 days. The extract was concentrated and poured into benzene, separating in benzene soluble and insoluble fraction. Benzene insoluble fraction was loaded onto a sintered column and then eluted with different solvents of increasing polarity. Elution with hexane-benzene (4: 6) yielded compound 1.

Compound 1 was obtained on elution with hexane-benzene (4: 6). Yield $400 \mathrm{mg}$, (Found: C, 67.88; H, 8.90. $\mathrm{C}_{39} \mathrm{H}_{61} \mathrm{O}_{10}$ required: $\mathrm{C}, 67.90 ; \mathrm{H}, 8.91 \%$ ); IR $v_{\max }$ : 3500, $3300,2928,1690,1100 \mathrm{~cm}^{-1},{ }^{1} \mathrm{H}$ NMR $\left(\delta \mathrm{CDCl}_{3}\right): 0.78-1.36$ $(18 \mathrm{H}, \mathrm{s}, 6 \mathrm{X} \mathrm{Me}), 0.94(3 \mathrm{H}, \mathrm{d}, \mathrm{J} 6.4 \mathrm{~Hz}$ at C-30), $5.31(1 \mathrm{H}, \mathrm{t}$, C-12 olefinic proton), 2.58 (1H, brs, $19-\alpha-\mathrm{OH}$ group), 2.51 $(1 \mathrm{H}, \mathrm{s}, 18 \beta \mathrm{H}), 4.06(1 \mathrm{H}, \mathrm{m}, \mathrm{J} 5.0 \mathrm{~Hz}, \mathrm{C}-2), 5.01$ (1H, d, J 5.0 $\mathrm{Hz}, \mathrm{C}-3$ ), 4.32 and 4.51 (each $1 \mathrm{H}, \mathrm{d}, \mathrm{J} 12.2 \mathrm{~Hz}$ for $\mathrm{CH}_{2} \mathrm{OH}$ group protons), 4.98 (1H, d, J $7 \mathrm{~Hz}$ for $\beta$ linkage), 3.2-3.8 $\left(5 \mathrm{H}, \mathrm{m}\right.$, for sugar protons), ${ }^{13} \mathrm{C}$ NMR as mention in Table-[I].

An ethanolic solution of 1 was refluxed with $7 \% \mathrm{H}_{2} \mathrm{SO}_{4}$ for $2 \mathrm{~h}$ and then poured in ice-cold water, separated yellow solid was crystallized from ethyl acetate obtain aglycone $1 \mathrm{a} .{ }^{1} \mathrm{H}$ NMR $\left(\delta \mathrm{CDCl}_{3}\right): 0.78-1.36(18 \mathrm{H}, \mathrm{s}, 6 \mathrm{X} \mathrm{Me}), 0.94(3 \mathrm{H}, \mathrm{d}, \mathrm{J}$ $6.4 \mathrm{~Hz}$ at C-30), 5.31 (1H, t, C-12 olefinic proton), $2.58(1 \mathrm{H}$, brs, 19- $\alpha-\mathrm{OH}$ group), $2.51(1 \mathrm{H}, \mathrm{s}, 18 \beta \mathrm{H}), 4.06(1 \mathrm{H}, \mathrm{m}, \mathrm{J} 5.0$ $\mathrm{Hz}, \mathrm{C}-2), 5.01$ (1H, d, J 5.0 Hz, C-3), 4.32 and 4.51 (each $1 \mathrm{H}$, d, J $12.2 \mathrm{~Hz}$ for $\mathrm{CH}_{2} \mathrm{OH}$ group protons); EI MS m/z, $558\left(\mathrm{M}^{+}\right)$, 527, 324, 264, 234, 219, 218, 216, 205, 201, 200.

\section{CONCLUSION}

In this research work, I found compound 1 that is compound-2,3-diacetoxy-19-hydroxy-urs-12-ene-24-O- $\beta$-D -xylopyranoside 1 which is successfully experimented and result is mentioned in Table- 1 . This compound found from rhizomes of cypersus scarious. Structure of compound 2, 3-diacetoxy-19-hydroxy-urs-12-ene-24-O- $\beta$-D-xylopyranosi de 1 is given figure-VI.

As per future point of view, it is possible to find other compounds from rhizomes of cypersus scarious that may be belong to same family or others also. 


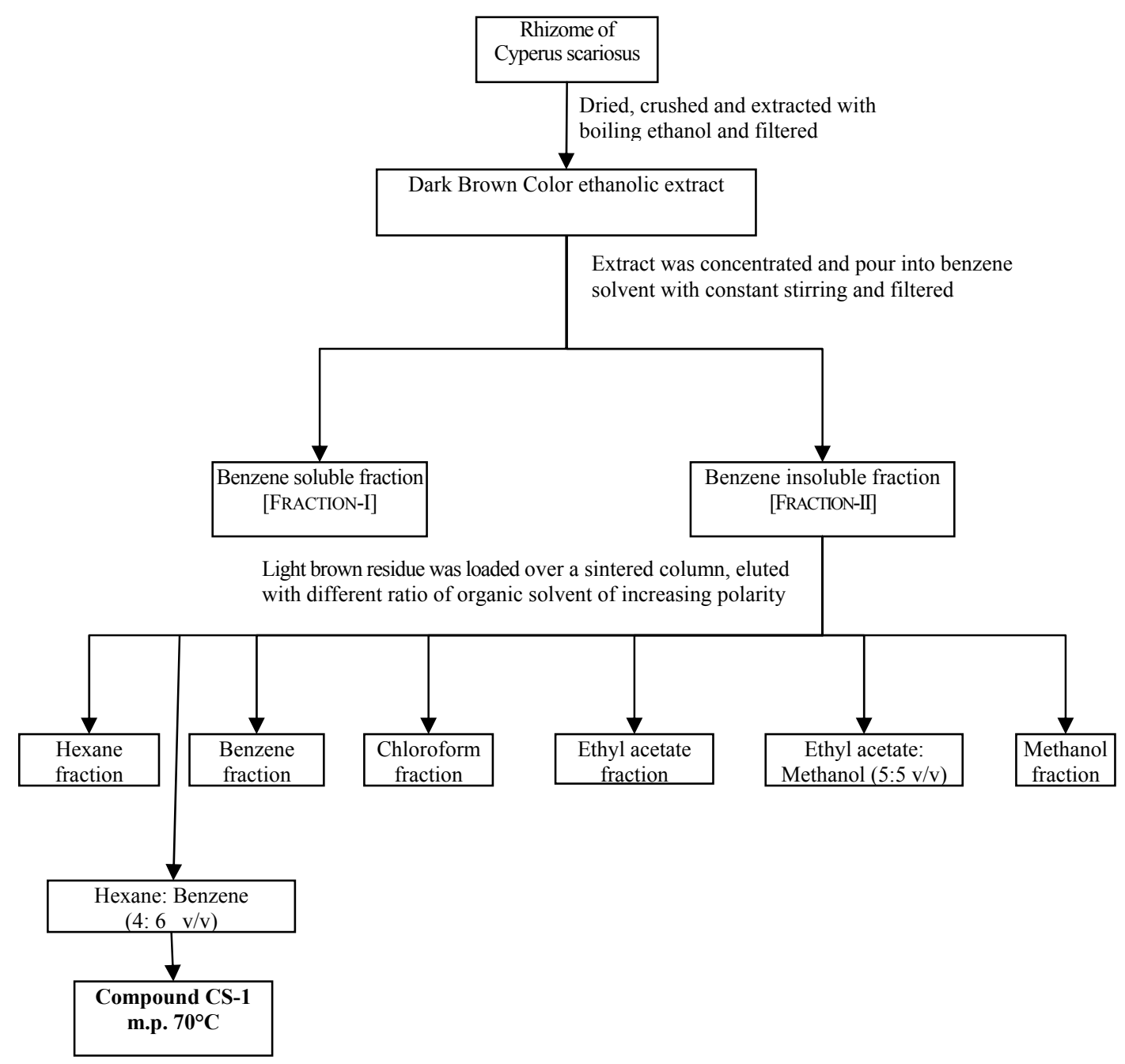

Fig-5: Scheme of Isolation and Purification of Compounds from the Rhizome of Cypetus Scarious

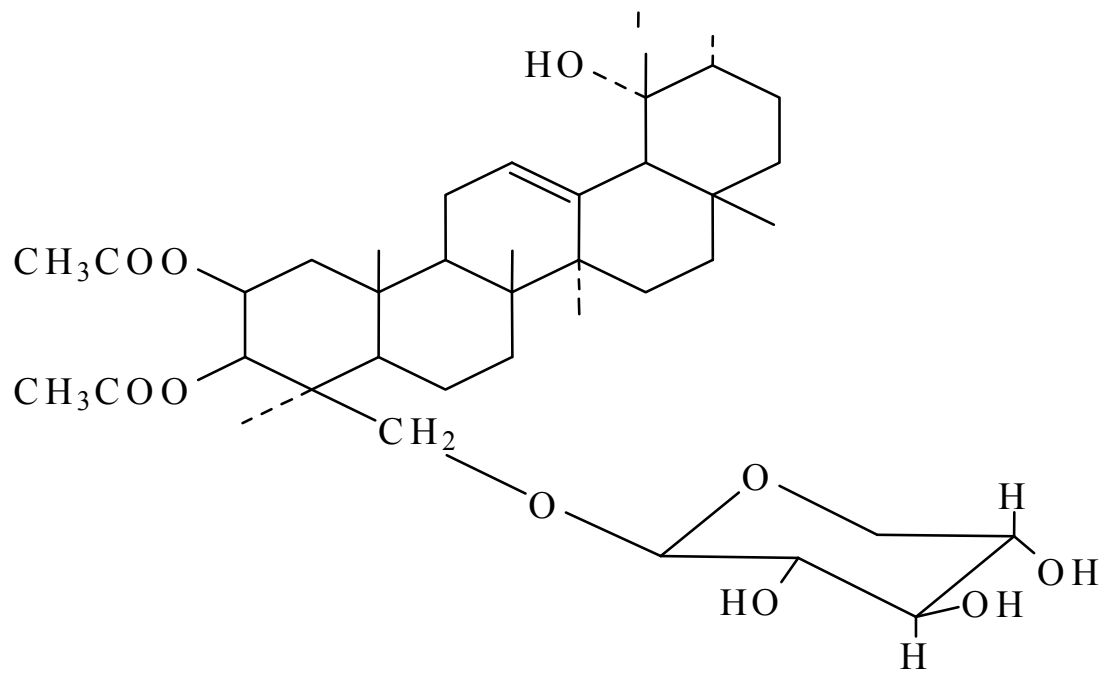

Fig.:VI- compound 2, 3-diacetoxy-19-hydroxy-urs-12-ene-24-O- $\beta$-D-xylopyranoside 1 
International Journal of Chemical Engineering and Applications, Vol. 1, No. 1, June 2010

ISSN: 2010-0221

Table-[1]: ${ }^{13} \mathrm{C}$ NMR spectra of compound 1 and $1 \mathrm{a}(75 \mathrm{MHz}, \delta$ in ppm from TMS, CDC13 as solvent)

\begin{tabular}{|c|c|c|}
\hline $\mathrm{C}$ & 1 & $1 \mathrm{a}$ \\
\hline 1 & $45.9(\mathrm{t})$ & $46.8(\mathrm{t})$ \\
\hline 2 & 70.6 (d) & 69.8 (d) \\
\hline 3 & $80.8(\mathrm{~d})$ & $79.9(\mathrm{~d})$ \\
\hline 4 & $43.2(\mathrm{~s})$ & $43.2(\mathrm{~s})$ \\
\hline 5 & $50.1(\mathrm{~d})$ & 49.9 (d) \\
\hline 6 & $19.9(\mathrm{t})$ & $19.2(\mathrm{t})$ \\
\hline 7 & $33.5(\mathrm{t})$ & $33.2(\mathrm{t})$ \\
\hline 8 & $42.1(\mathrm{~s})$ & $41.2(\mathrm{~s})$ \\
\hline 9 & $48.6(\mathrm{~d})$ & $48.2(\mathrm{~d})$ \\
\hline 10 & $37.5(\mathrm{~s})$ & $38.2(\mathrm{~s})$ \\
\hline 11 & $24.7(\mathrm{t})$ & $24.3(\mathrm{t})$ \\
\hline 12 & $126.5(\mathrm{~d})$ & $126.2(\mathrm{~d})$ \\
\hline 13 & $142.2(\mathrm{~s})$ & $141.1(\mathrm{~s})$ \\
\hline 14 & $42.1(\mathrm{~s})$ & $42.3(\mathrm{~s})$ \\
\hline 15 & $28.0(\mathrm{t})$ & $28.1(\mathrm{t})$ \\
\hline 16 & $27.3(\mathrm{t})$ & $27.0(\mathrm{t})$ \\
\hline 17 & $38.5(\mathrm{~s})$ & $39.2(\mathrm{~s})$ \\
\hline 18 & $44.5(\mathrm{~d})$ & $44.3(\mathrm{~d})$ \\
\hline 19 & $72.6(\mathrm{~s})$ & 72.4 (d) \\
\hline 20 & $42.1(\mathrm{~d})$ & $42.1(\mathrm{~d})$ \\
\hline 21 & $26.2(t)$ & $26.9(\mathrm{t})$ \\
\hline 22 & $35.9(\mathrm{t})$ & $35.9(\mathrm{t})$ \\
\hline 23 & $23.1(q)$ & $23.6(q)$ \\
\hline 24 & $73.9(\mathrm{t})$ & $63.9(\mathrm{t})$ \\
\hline 25 & $17.2(\mathrm{q})$ & $17.3(q)$ \\
\hline 26 & $17.5(q)$ & $17.4(q)$ \\
\hline 27 & $25.1(q)$ & $25.2(q)$ \\
\hline 28 & $21.2(\mathrm{q})$ & $21.2(q)$ \\
\hline 29 & $27.5(q)$ & $27.4(q)$ \\
\hline 30 & $17.2(q)$ & $17.1(q)$ \\
\hline$-\mathrm{OCOCH}_{3}$ & $170.52(\mathrm{~s})$ & $170.52(\mathrm{~s})$ \\
\hline$-\mathrm{OCOCH}_{3}$ & $170.13(\mathrm{~s})$ & $170.13(\mathrm{~s})$ \\
\hline$-\mathrm{OCOCH}_{3}$ & $21.3(\mathrm{q})$ & $21.3(\mathrm{q})$ \\
\hline$-\mathrm{OCOCH}_{3}$ & $20.7(q)$ & $20.7(q)$ \\
\hline \multicolumn{3}{|l|}{ Sugar moiety } \\
\hline 1 & $103.5(\mathrm{~d})$ & - \\
\hline 2 & $71.2(\mathrm{~d})$ & - \\
\hline 3 & $75.3(\mathrm{~d})$ & - \\
\hline 4 & $70.2(\mathrm{~d})$ & - \\
\hline 5 & $68.1(\mathrm{t})$ & - \\
\hline
\end{tabular}




\section{REFERENCES}

[1] R. N. Chopra, S. L. Nayar and I. C. Chopra, Glossary of Indian Medicinal Plants (CSIR, New Delhi), 1956, 89.

[2] J. D. Hooker, Flora of India, 1973, Vol VI, 612.

[3] E. Salkowski and Z. Hoppe-Seyler, 1908, 57, 521.

[4] R.Br. Bhatt, S.K. Saxena, V.K. Singh, Indian J. Phys. Nat. Sci., 2(A), 15-17 (Eng), 1982.

[5] Phytochemistry, 20(11), 2605 (Eng.), 1981.

[6] Y. Gopichand, P.R. Pednekar, K.K. Chakravarti, Indian J, Chem. Sect. B, 16B (2), 148-9 (Eng.), 1978.

[7] O.N. Guha Bakshi, P. Sensarma, D.C. Pal, A Lexicon of Medicinal Plants in India, Vo.-I, 526, April 15, 1999.

[8] C. Liebermann, Ber dt Chem Ges, 1985, 1804.

[9] Tschugajew, Chem, Zig, 1900, 24, 542.

[10] C. R. Noller, R. A. Smith, G. H. Harris and J. W. Walker, J Amer Chem Soc, 1942, 64, 3047.

[11] Rosenheim, J Biochem, 1929, 23, 47.

[12] Stoll and E. Jacker in Modern Methods of Plant Analysis edited by K. Peach and M. V. Tracey, Springer-Verlag, 1955, 3, 64.

[13] C. H. Brieskorne and M. Briner, Pharm Acta Helve, 1953, 28,139.

[14] L. Ruzicka and Liebigs, Ann. Chem, 1929, 25, 471.

[15] Guillermo Delgado, Julio Hernandez, Rogelio Pereda-Miranda, Phytochemistry, 1989, Vol 28, No 5, 1483-1485.

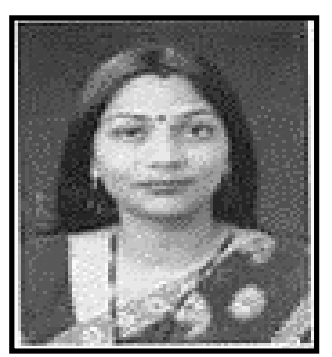

Dr. Shachi Sahu received B.Sc. (Chemistry Group) from University of Allahabad, Allahabad (U.P.)-India in year 1998, M.Sc. (Organic Chemistry) from University of Allahabad, Allahabad (U.P.)-India in year 2001, and Ph.D. (Organic Chemistry, Titled: Structural Studies on Some Plant Constituents) from University of Allahabad, Allahabad (U.P.)-India in year 2006. She worked as a Lecturer in the department of organic chemistry at University of Allahabad during 2003 to 2006. Now she is working as an Asst. Professor in the Department of Engg Chemistry at Technocrat Institute of Technology \& excellence-Bhopal (M.P.) India since 2007. Her Area of interest included isolated, separated, and purified the constituents of the medicinal plant and identified with the help of chemical method and spectral studies like UV, IR, and ${ }^{1} \mathrm{H} N M R,{ }^{13} \mathrm{C}$ NMR and mass spectra. She is having 04 papers in International Journals (Int J. Chem. Model., Int. J. Environmental Science, Indian Journal of Chemistry, and IJCEA), 02 papers in International Conferences. Dr. Sahu is member of IACSIT. She is very hardworking, laughing nature, and believed in team work.

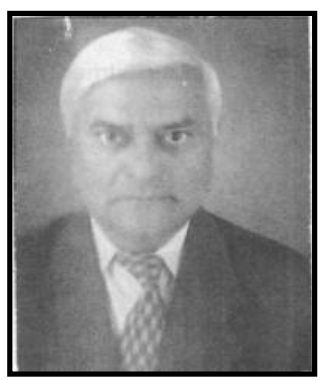

Dr. (Prof.) Jagdamba Singh is a professor in the department of Chemistry, University of Allahabad, Allahabad. He has long (over 28 years) teaching and research experience in varied fields. He has published over 100 research papers in national and international journals with high impact factors. So far thirty students have obtained D.Phil degree under his guidance. His field of research is natural products Chemistry, Green chemistry and synthetic organic Chemistry. Senior commonwealth academic staff fellowship (1985) was awarded to him at Chemistry department, university of Glasgow.U.K., Indo -Hungarian Cultural Exchange fellowship was awarded to him in 1988. Dr. Singh has participated and delivered lectures at various national and international symposia. $\mathrm{He}$ is also member of several professional societies. Dr. Singh has written several books for undergraduate and postgraduate students.

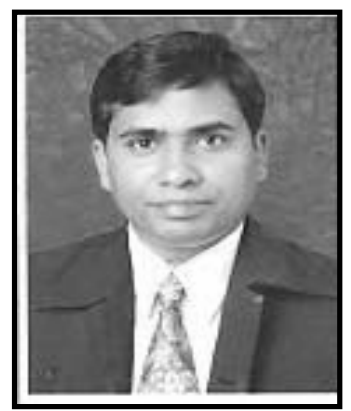

Shiv Kumar received Diploma (Lather Technology) from Govt. Lather Institute of Agra (U.P.)-India in year 2000. He worked as a Tanner in Ajaction Lather Punjab Ltd. Punjab in between 2000 to 2001. After that he completed B. Tech. (Information Technology) degree from Bhagwant Institute of Technology (U.P.)-India in year 2004, M. Tech. (Information Technology) degree from Technocrats Institute of Technology/ R.G.T.U.-Bhopal(M.P.)
-India in year 2010. He worked as a lecturer in C.S.E. / I.T. department at CEC-Bilaspur (C.G.)-India in between Dec-2004 to April-2006 and SSCET-Bhilai(C.G.)-India in between May-2006 to August-2006. Now he is working as an Asst. Professor at Technocrat Institute of Technology-Bhopal (M.P.) India. His research interests include Voice Signal Compression, Tonality Computation, Image Processing, and Spectrum Analysis of Signal. $\mathrm{He}$ is having 16 papers in International Journals (IEEE Xplore ${ }^{\mathrm{TM}}$ Digital Library, IEEE CS Digital Library, IJCEE, IJET, CiiT International Journal of Digital Signal Processing, CiiT International Journal of Image Processing, and WSP), 07 papers in International Conferences, 8 papers in National Conferences, and 01 Text Book. He is member of IACSIT \& IAENG. He is very hard working and believed in work. 